\title{
Türkiye’deki Bankaların Sektörler Bazında Kullandırdıkları Krediler İle Ekonomik Büyüme Arasındaki İlişki: 1999-2011
}

Selahattin KOÇ*

\section{ÖZET}

Türkiye'de finansal yapı içerisinde bankaların yeri oldukça önemlidir. Bankalar piyasaların ihtiyaç duyduğu fonların sağlanmasında, değerlendirilmesinde ve finansal piyasaların sağllklı bir biçimde işlemesinde önemli görevler üstlenmektedir. Bankalar, fonların sağlanması ve değerlendirilmesi açısından, Türkiye'de faaliyetlerini yürüten birçok işletmenin finansal yapılart içerisinde de oldukça önemli bir yere sahiptir. Bundan dolayı bankaların sektörlere göre kullandırdıkları krediler ile ekonomik büyüme arasında uzun ya da kısa dönemdeki ilişkilerin tespit edilmesi, söz konusu ilişkilere göre politika geliştirilmesini mümkün kllmaktadır. Bu çalışmada, Türkiye'deki bankaların 1999-2011 yılları arasında kullandırdıkları krediler içerisinde ilk 10 sirada yer alan sektörlere ait kredi miktarları ile ekonomik büyüme arasındaki ilişki, Panel Veri Analizi yapılarak incelenmiştir. Elde edilen sonuçlara göre, bankaların kullandırdiğg krediler içinde ilk on sirada yer alan sektörler ile ekonomik büyüme arasında uzun dönemli pozitif yönlü bir ilişkinin olduğu görülürken, klsa dönemde herhangi bir ilişkinin olmadığ tespit edilmiştir.

Anahtar Kelimeler: Banka Kredileri, Ekonomik Büyüme, Panel Veri Analizi.

JEL Sinıflandirması: G21, O16, C33.

Relationship Between Economic Growth and Sector Based Credits Loaned by Banks in Turkey : (1999-2011)

\section{ABSTRACT}

Banks have a really remarkable position In Turkey's financial structure. Banks have significant tasks in both accomodation and evaluation of the fonds needed by the market, and operation of the market in a healthy way. They are also important for the financial structures of many firms operating in Turkey in terms of accomodation and evaluation of the fonds. Therefore, determining the short-term or long-term relationship between economic growth and the sectoral credits provided by banks, makes it possible to constitute policies based on these relationships. In this study, the relationship between the economical growth and the credit amounts that were provided by the banks to the top ten sectors (in credit amount) between 1999 and 2011 in Turkey were examined using the Panel Data Analysis. As a result, it is determined that there is a positive relationship between the provided credits and economical growth in long term but there is no such relationship in short term.

Keywords: Bank Credits, Economical Growth, Panel Data Analysis.

Jel Classification: G21, O16, C33.

\footnotetext{
* Yrd. Doç. Dr. Selahattin Koç, Cumhuriyet Üniversitesi, İktisadi ve İdari Bilimler Fakültesi, skoc@cumhuriyet.edu.tr
} 


\section{GİRIŞ}

Doğrudan finansman kaynakları denildiğinde menkul kıymetler tanımlanırken, dolaylı finansman kaynakları denildiğinde de kredi piyasası akla gelmektedir. Mali sistemler içerisinde çeşitli yapıda birimler (bankalar, aracılar, vb.) bulunmaktadır. Bunların en önemli görevi piyasalarda fon fazlası olanlar ile fon gereksinimi olanları bir araya getirerek sürecin sağlıklı bir biçimde işlemesini sağlamaktır. Mali sistemlerin gerçekleştirmiş olduğu bu fon aktarımından dolayı tasarruflar yatırımlara dönüşmekte ve böylece sermaye stoku artmaktadır. Piyasalara dolaylı finansman sunanlar ellerindeki fazla fonları bir aracı kuruma (bankalara) yatırmakta, fon ihtiyacı olanlar ise fonları aracı kurumlardan miktar, süre ve maliyet uygunluğu sağlayarak karşılamaktadırlar (Güven, 2002). Bankaların sunmuş olduğu kredi sisteminin doğru bir biçimde işlemesi, ülke ekonomilerindeki kırılganlığı azaltmakta, sürdürülebilir büyüme ve kalkınmaya katkı sunmaktadır. Piyasaların derinliği ve parasal işlem hacimleri ne kadar artarsa, piyasa riskleri aynı ölçüde azalmaktadır. Bu bağlamda bankalar tasarrufların değerlendirilmesinde, piyasaların fonlanmasında ve piyasalar arası bütünleşmenin sağlanmasında önemli görevler üstlenmiş durumdadır.

Son yıllarda finansal piyasalarda oluşturulan fonlara bakıldığında, bankacılık sektörünün payının oldukça önemli olduğu görülmektedir. Bankacılık sektörü tarafından oluşturulan bu fonların büyüme üzerinde etkisinin olup olmadığı son zamanlarda birçok çalışmada test edilmiştir. Türkiye'deki bankaların sektörler itibariyle kullandırdığı kredilerden hangilerinin büyüme üzerinde daha çok etkiye sahip olduğunun tespit edilmesi, süreç içerisinde geliştirilecek politikalar açısından oldukça anlamlı ve önemlidir.

Ekonomik büyüme ile banka kredileri arasındaki ilişki konusunda yapılan çalışmaların birçoğunda özellikle uzun dönemde pozitif yönlü bir ilişkinin olduğu vurgusu yapılmıştır. Piyasaların etkin bir şekilde çalışabilmesi ve yatırımların doğru bir biçimde yapılabilmesi için etkin bir kaynak hareketliliği ve piyasaların kullanacağı fonların artması gerekmektedir. $\mathrm{Bu}$ durumu gelişmiş ülkelerde açık bir şekilde görebilmek mümkündür. Hükümetler büyüme politikalarını geliştirirlerken mali sektörlerdeki genişlemeyi de dikkate alırlar. Ekonomik büyüme ve gelişmede bankaların kullandırmış oldukları kredilerin anahtar rol oynadığı vurgulanmaktadır (Khan ve Senhadji, 2000). Bu konu ile ilgili yapılan çalışmalarda, finansal sistemin, özellikle de bankaların iyi organize olduğu ve kredi siteminin sağlıklı işlediği ülkelerde gelişmenin ve büyümenin daha hızlı olduğu belirtilmiştir. Diğer taraftan kredi sisteminin sağlıklı işlemediği piyasalarda hem bankalar hem de diğer piyasa oyuncuları açısından aşırı risklerin oluştuğu ifade edilmiştir (Kasekende, 2008). Bankalar fon fazlalıkları ile fon gereksinimleri olan kişi ya da kuruluşlar arasında bağlantıyı sağlayan kurumlardır. Fon arz edenler ile fon talep edenler arasındaki sistemin sağlıklı bir biçimde işlemesi, dış finansmana olan gereksinimin azalmasını sağlamaktadır. Bunun yanında sektörlere sunulan kredilerin genişlemesinin de sanayinin ve yatırımların gelişmesini olanaklı kıldığ belirtilmiştir (Mishkin, 2007). 
Türkiye'de, finansal piyasaları ağırlıklı olarak bankacılık sektörü belirlemektedir. Dolayısıyla bankacılık sektörü; ülkenin ekonomik yapısının şekillenmesine, piyasaların genişlemesine ve finansal piyasalara dönük politikaların geliştirilmesine etki etmektedir. Bir ülke ekonomisinin gelişmesine ve büyümesine etki eden birçok faktör bulunmaktadır. Bunlardan birisi de bankaların toplam piyasalar ve sektörler itibariyle kullandırmış olduğu kredilerin hacmidir. Daha önceki çalışmalara bakıldığında, daha çok kullandırılan toplam krediler ile ekonomik büyüme arasındaki ilişki incelenmiştir. Bu konuda iki farklı yaklaşımdan söz edilebilir. Bunlardan ilki, bankaların kullandırmış olduğu kredilerin ekonomik büyümeyi tetiklediği, ikincisi ise ekonomik büyümenin kullandırılan banka kredilerini arttırdığı yönündedir. Bankaların kullandırdığı krediler ile ekonomik büyüme arasındaki başka bir araştırma konusu ise kullandırılan kredilerin büyüme üzerinde uzun dönemli mi yoksa kısa dönemli mi bir etkiye sahip olduğudur. Yapılan çalışmalarda ağırlıklı görüş banka kredilerinin uzun dönemde ekonomik büyümeyi olumlu yönde etkilediğidir.

Son yıllarda yaşanan krizler nedeni ile Türkiye'deki bankalar daha çok likit kalmayı tercih etmişlerdir. Çünkü gelecek belirsizliğinin arttığı bir ortamda bankalar daha az kredi kullandırma eğilimi içerisine girmişlerdir. Bu dönemlerde geri ödenmeyen krediler artmış, şirketlerin iflas etme risklerinden dolayı da bankalar daha seçici davranmak zorunda kalmışlardır. Ayrıca bankalara yatırılan mevduatların vadelerinin kısalması da bankaların uzun vadeli kredi kullandırmalarını zorlaştırmıştır. Sürecin bu şekilde geliştiği bir ekonomide büyümenin durması veya negatif olarak gerçekleşmesi kullanılan kredilerin azalmasına neden olmuştur. Diğer taraftan krediler daraldığı için ekonominin büyümediği ya da kötüleştiği görülmüştür. Yaşanan krizler ve riskler sonrası daha doğru teşhis ve tedavilerin oluşturulabilmesi için finansal sistem ile büyüme arasındaki ilişkinin yönünün tespit edilmesi gerekmektedir (Güven, 2002).

Bu konu ile ilgili önemli çalışmalara bakıldığında özellikle iç piyasalara kullandırılan kredilerin büyüme üzerinde olumlu etkisinin olduğu ve ekonomik gelişmişliğe göre farklılık gösterdiği belirtilmiştir (Aghion vd., 2005; Rousseau ve Wachtel, 2002). Fakat gerçek ekonomik hayatta hane halkı ve firmaların aşırı borçlanmasının ekonomik büyüme üzerinde negatif etkisinin olacağı gözardı edilmemelidir (Leitao, 2012).

Bu çalışmada daha önceki çalışmalardan farklı olarak, bankalar tarafından piyasalara kullandırılan kredi toplamının ekonomik büyümeye etkisi değil de bankaların sektörler bazında kullandırmış olduğu kredilerin ekonomik büyümü üzerinde herhangi bir etkisinin olup/olmadığının araştırılması yapılmaktadır. Amaç hangi sektörün/sektörlerin büyüme üzerinde etkisinin olduğunun tespit edilmesi, ona göre ekonomik ve finansal sürecin şekillendirilmesine yardımcı olmaktır.

$\mathrm{Bu}$ çalışmada test edilecek hipotezler aşağıdaki gibi geliştirilmiştir

Hipotez 1= $\mathbf{H}_{\mathbf{0}}=$ Bankaların sektörler itibariyle kullandırmış oldukları krediler ile ekonomik büyüme arasında kısa dönemli pozitif yönlü bir ilişki vardır. 
Hipotez 2= $\mathbf{H}_{\mathbf{0}}=$ Bankaların sektörler itibariyle kullandırmış oldukları krediler ile ekonomik büyüme arasında uzun dönemli pozitif yönlü bir ilişki vardır.

Rousseau ve Wachtel (2002), bankalar tarafından iç piyasa da kullandırılan kredilerin büyüme üzerinde etkisinde farklı görüşlerin olduğunu ileri sürmüşlerdir. Bazı çalışmalarda iç piyasa da kullandırılan kredilerin ekonomik büyüme üzerinde pozitif etkisinin olduğu belirtilirken, bazı çalışmalarda ise iç piyasada kullandırılan kredilerin büyüme üzerinde etkisinin olmadığı yada negatif etkisinin olduğu belirtilmektedir. Ancak, Shaw (1973), Hassan vd. (2011), ile Rousseau ve Wachtel (2011) kredi patlamasının hem teorik hem de uygulamalı olarak bankacılık sistemini zayıflatma olasılığını artırdığı gibi, enflasyonist bir bask1 oluşturacağını ileri sürmüşlerdir.

\section{LITERATÜR TARAMASI}

Finansal gelişme ile ekonomik büyüme arasında ilişkileri ölçmek için bir çok çalışma yapılmıştır. Bu çalışmaların başında da King ve Levine (1993) ile Levine (1997)'nin yapmış olduğu 1960-1989 yılları arasında 80 ülkeyi kapsayan anket çalışması gelmektedir. Belirtilen yazarlar yapmış oldukları çalışmalarında finansal gelişme ile ekonomik büyüme arasında uzun dönemli güçlü ilişkinin olduğu sonucuna ulaşmışlardır. Yine aynı çalışmada, büyümenin, finansal gelişmeden ekonomik büyümeye doğru olduğunu belirtmişlerdir. De Gregorio ve Guidotti (1995), yapmış oldukları çalışmalarında King ve Levine (1993) ile Levine (1997) tarafından yapılan çalışmayı destekler nitelikte ve benzer sonuçlar sağladıklarını ileri sürmüşlerdir.

Güven (2002), yazmış olduğu makalede Türkiye'de kullandırılan banka kredileri ile ekonomik büyüme arasındaki ilişkinin yönünün uzun dönemli, krediden ekonomiye doğru olduğunu belirtmiştir. Bankacılık sektörü tarafından kullandırılan kredilerin büyümeye dönük politikaların kritik bir unsuru olduğu vurgusunu yapmıştır. Öztürkler ve Çermikli (2007) tarafindan gerçekleştirilen çalışmada ise büyüme ölçütü olarak 1990-2006 dönemi sanayi üretim endeksini kullanarak büyüme ile krediler arasındaki ilişkiyi Vektör Otoregresyon ve Granger nedensellik testi ile ölçmeye çalışmışlar, bankalar tarafından kullandırılan krediler ile büyüme arasında iki yönlü nedensel ilişkinin olduğunu belirtmişlerdir.

Levine (1997), tarafından yazılan makalede ülkelerdeki finansal gelişmişliğin, yatırımcıların firmaların yönetimi hakkında sağladıkları bilgiler ile işlem maliyetlerini azalttığını ileri sürmüştür. Yine aynı makalede finansal piyasaların gelişmesinin kaynak dağılımında etkinliği sağladığı ve uzun dönemde ekonomik büyümeye katkı sağladığı gibi risk yönetme imkanlarını ve likit finansal varlıkları artırdığı ifade edilmiştir.

Levine ve diğ. (2000), 71 farklı ülkede 1960-1995 yılları arasındaki verileri kullanarak yapmış oldukları çalışmalarında banka kredileri ile ekonomik büyüme arasında pozitif yönlü güçlü ilişkinin olduğu sonucuna ulaşmışlardır. 
Leitao (2012), 1990-2010 yıllarında Euro (27) bölgesini kapsayan çalışmasında banka kredileri ile ekonomik büyüme arasında ilişkiyi araştırmıştır. Çalışmasında panel veri kullanmış, banka kredilerinin Euro bölgesinde yatırım aktivitesini yavaşlattığını ve dolayısıyla ekonomik büyümeyi olumsuz yönde etkilediğini ifade etmiştir. Yılmazkuday (2011) 1965-2004 yılları arasında 84 ülkeyi kapsayan çalışmasında da, ülkelerdeki enflasyonun uzun dönemde ekonomik büyümeyi olumsuz yönde etkilediğini belirtmiştir.

Aghion vd. (2005) ile Rousseau ve Wachtel (2002), tarafından yapılan ve bu alanda önemli atıflar alan çalışmalarında, iç piyasada kullandırılan kredilerin ekonomik büyümeyi teşvik ettiğini belirtmişlerdir.

Saarenheimo (1995), banka kredi arzındaki değişimin özel yatırımlar üzerindeki etkilerini VAR(vector auto regression) yöntemi ile araştırmıştır. Bankalar tarafından kullandırılan kredilerin modele dahil edilmesiyle birlikte, büyüme ile krediler arasındaki ilişkinin anlamlılığını yitirdiğini belirtmiştir. Ghirmay (2005), Sub-Saharan Afrika'sının 13 ülkesinde finansal gelişme seviyesi ile ekonomik büyüme ararsındaki ilişkiyi ölçmek için VAR yöntemini kullanmış. 13 ülkenin 12'sinde uzun dönemde, finansal gelişmişlik seviyesi ile ekonomik büyüme arasında pozitif yönlü bir ilişkinin olduğunu ileri sürmüştür. Yine aynı çalışmada, 13 ülkenin 6'sında finansal gelişme ve büyüme arasında çift yönlü nedensel ilişkinin olduğu da belirtilmiştir.

Sanusi ve Salleh (2007), Malezya ülkesinde 1960-2002 yıllarını kapsayan çalışmalarında, bankalar tarafından kullandırılan kredilerin, ekonomik büyüme üzerinde pozitif yönlü bir etkisinin olduğu yönünde tespitleri olmuştur. Khan ve Senhadji (2003), finansal gelişme ile ekonomik büyüme arasında istatistiki olarak anlamlı ve pozitif yönlü bir ilişki, Khan vd. (2005), finansal gelişme ile ekonomik büyüme arasında uzun dönemde pozitif yönlü bir ilişki fakat kısa dönemde negatif yönlü bir ilişki olduğunu ileri sürmüşlerdir. Kiran vd. (2009), gelişmekte olan ülkeleri kapsayan ve 1968-2007 yıllarına ait verileri kullandığ1 çalışmalarında, finansal gelişme ile ekonomik büyüme arasında istatistiki olarak anlamlı ve pozitif yönlü bir ilişki olduğu tespitini yapmışlardır. Yine, King ve Levine (1993), Levine ve Zervos (1998), Rajan ve Zingales (1998), Jalilian ve Kirkpatrick (2002), Calderon ve Liu (2002) ile Beck ve Levine (2004) yapmış oldukları ampirik çalışmalarında finansal gelişme ile ekonomik büyüme arasında pozitif yönlü bir ilişkinin olduğunu belirtmişlerdir. Lucas (1988), Ahmed (2008), yapmış oldukları çalışmalarında ise banka kredileri ile ekonomik büyüme arasında negatif yönlü bir ilişsinin olduğunu belirtmişlerdir.

\section{DATA VE KULLANILAN YÖNTEM}

Bilimsel çalışmalar, banka kredileri ile ekonomik büyüme arasında doğrusal bir ilişkinin olduğu yönündedir. Ekonomik büyüme ve banka kredileri arasında doğrusal ilişkinin olduğunu ileri sürenler değişik analiz yöntemlerini kullanmışlardır. King ve Levine (1993), cross country growth regression yöntemini (çapraz ülke büyüme regresyon modeli), Rioja ve 
Valev (2003), panel veri tekniklerini ve Demetriades ve Hussein (1996), zaman serileri yöntemini kullanmışlardır.

$\mathrm{Bu}$ çalışmada veriler TCMB EVD siteminden sağlanmıştır. Bankalar kullandırdıkları kredileri 31 sektöre ayırmışlardır. Bu çalışmada, bankalar tarafından sektörler bazında kullandırılan krediler içersinde ilk on sırada yer alanlar analize tabi tutulmuştur. Veriler 1991:1-2011:12 yıllarına ait aylık verilerden oluşmaktadır. Büyüme değişkeni olarak aynı yıllara ait aylık sanayi endeksi verileri kullanılmıştır(1991:1 100 baz alınmıştır). Yöntem olarak “Panel Veri Analizi” kullanılmıştır. Bu yöntem, değişkenlerin hem zaman hem de yatay kesit boyutunda değerlendirilmesine imkân tanıdığı ve bu değişkenlerin açıklayıcı gücünü artırdığı için tercih edilmiştir. Panel veri yöntemi, yatay kesit verilerinin birbirlerinden farklılık göstermesi durumunu farklı zaman boyutlarıla dikkate almasından dolayı, ekonometrik analizlerde araştırmacılara büyük destek sağlamaktadır (Erem, 2013). Analiz yapılırken Eviews 7.1 paket programı kullanılmıştır. Bağımlı ve bağımsız değişkenler arasındaki ilişkiye dair model aşağıdaki gibi kurulmuştur.

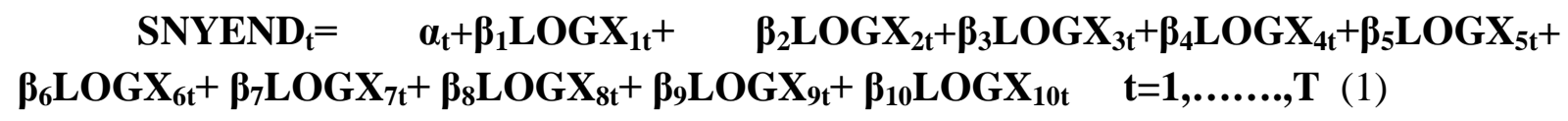

Modelde X; bankaların kredi kullandırdıkları sektörleri, t dönemleri temsil ederken, T ise toplam dönem sayısını göstermektedir.

Çalışmada kullanılan bağımlı değişken ile bağımsız değişkenler şunlardır:

SNYEND= Sanayi Endeksi

X1= Tekstil ve Tekstil Ürünleri Sanayi

X2= Toptan ve Perakende Ticareti, Komisyonu ve Motorlu Araçlar Servis Hizmeti

X3= Gıda, Meşrubat ve Tütün Sanayi

X4=İnşaat Sektörü

X5= Metal Ana Sanayi ve İşlenmiş Madde Üretimi

X6=Finansal Aracılık

X7=Bireysel Krediler ve Kredi kartları

$\mathbf{X 8}=$ Taşımacılık, Depolama ve Haberleşme

X9=Elektrik, Gaz ve Su Kaynakları

X10=Tarım, Avcılık ve Ormancılık

\section{Birim Kök Testleri}

Sektörler bazında kullandırılan banka kredileri ile ekonomik büyüme arasındaki kısa ve uzun dönemdeki ilişkileri araştırılmadan önce, bu değişkenlere ait birim kök sınaması yapılmıştır.

Sınır testi yaklaşımına göre serilerin bütünleşme derecelerinin I(0) ya da I(1) olmas1 gerekmektedir. Serilerin durağanlığı, Dickey ve Fuller (1981) tarafından geliştirilen Dickey- 
Fuller (ADF-Augmented Dickey-Fuller) birim kök testi kullanılarak incelenmiştir. DickeyFuller testi için aşağıdaki (2) numaralı sabit terimli ve trendli model kullanılmıştır.

$$
\Delta Y_{t}=\alpha_{0}+\alpha_{1} Y_{t-1}+\sum_{i=1}^{p} \delta_{i} \Delta Y_{t-1}+\varepsilon_{t} \ldots \ldots \ldots \ldots \ldots \ldots \ldots \ldots \ldots \ldots \ldots \ldots \ldots \ldots \ldots \ldots
$$

$\boldsymbol{H}_{0}: \boldsymbol{\alpha}_{1}=\mathbf{0}$ Birim kök vardır, zaman serisi dură̆an de ğildir.

$\boldsymbol{H}_{1}: \alpha_{1} \neq \mathbf{0}$ Birim kök yoktur, zaman serisi dură̆andır.

Verilen regresyon denkleminde; $\mathrm{Y}_{t}$, ele alınan seriyi; $\Delta$, fark operatörünü; $\mathrm{k}$, denkleme ilave edilen bağımlı değişken gecikmelerini $\alpha$ ile $\delta$ parametreleri ve $\varepsilon_{t}$ ise hata terimini temsil etmektedir. Tahmin edilen (1) numaralı regresyon denkleminde ele alınan serinin durağan olup olmadığını belirlemek için $\beta_{1}$ parametresi kullanılır. Eğer hesaplanan ADF testi McKinnon'nun kritik değerinden yüksek ise $\boldsymbol{H}_{\boldsymbol{0}}$ hipotezi kabul edilir, seriler arasında birim kök alduğu anlamına gelir. $Y_{t}$ ve $\Delta Y_{t-1}$ verilerin serilerinde durağan olmadığını göstermektedir (Murty vd, 2012). Eğer zaman serileri düzeyde dırağan değil ise bu durumda birinci yada ikinci farkları alınrak durağanlık testi yapılmaktadır. Farkları alınarak kullanılan seriler için (3) numaralı regresyon denklemi kullanılmaktadır.

$$
\Delta^{2} Y_{t}=\Psi_{i} \Delta Y_{t-1}+\sum_{i=1}^{p} \theta_{i} \Delta Y_{t-1}+\varepsilon_{t}
$$

$\boldsymbol{H}_{\mathbf{0}}: \boldsymbol{\Psi}_{\mathbf{1}}=\mathbf{0}$ Birim kök vardır, zaman serisi dură̆an değildir.

$\boldsymbol{H}_{\mathbf{1}}: \boldsymbol{\Psi}_{\mathbf{1}} \neq \mathbf{0}$ Birim kök yoktur, zaman serisi dură̆andır.

Eğer zaman serisi birinci farkında durağan ise bu durumda $\Psi_{1} \neq 0$ olduğunu gösterir.

\section{Nedensellik Analizi}

Uzun dönem ilişsi içinde olduğu tahmin edilen iki yada daha fazla değişken arasındaki ilişkiyi tespit etmek amacı ile (4) ve (5) numaralı hata düzeltme regresyon modelleri kullanılmıştır.

$$
\begin{aligned}
& \Delta Y_{t}=\beta+\alpha_{11} u_{1, t-1}+\sum_{i=1}^{1} \delta_{i} \Delta Y_{t-i}+\sum_{i=1}^{r} \lambda_{i} \Delta X_{t-i}+\varepsilon_{1 t} \ldots \\
& \Delta Y_{t}=\beta+\alpha_{12} u_{1, t-1}+\sum_{i=1}^{k} \Psi_{i} \Delta X_{t-i}+\sum_{i=1}^{s} \emptyset_{i} \Delta Y_{t-i}+\varepsilon_{2 t} \ldots
\end{aligned}
$$

Zaman serileri arasında hata düzeltme modelinde nedensel ilişkilerin düzenlenmesi için (4) numaralı modelde $\sum_{i=1}^{r} \lambda i=0$ ve $\alpha_{11}=0$ ve (4) numaralı modelde $\sum_{i=1}^{s} \phi i=0$ ve $\alpha_{12}=0$ hipotezlerinin test edilmesi gerekir. Bu hipotezlerden $\sum_{i=1}^{r} \lambda i=0$ ve $\sum_{i=1}^{s} \phi i=0$ için “ $F$ ” veya 
“Walt" $\left(\chi^{2}\right)$ testi $\alpha_{11}=0$ ve $\alpha_{12}=0$ için “ $t$ " testi uygulanır. Ampirik çalışmalarda gecikme parametrelerinin testi ( $\sum_{i=1}^{r} \lambda i=0$ ve $\sum_{i=1}^{s} \emptyset i=0$ ) k1sa dönem nedensel etkinin, hata düzeltme terimlerinin testi, $\left(\alpha_{11}=0\right.$ ve $\left.\alpha_{12}=0\right)$ ise uzun dönem nedensel etkinin belirleyicisi olarak değerlendirilmektedir (Ceylan ve Durakaya, 2010).

Johansen Eşbütünleşme Analizi: $\mathrm{Bu}$ analiz yöntemi, değişkenler arasında uzun dönemli bir ilişkinin var olup/olmadığını test etmek için yaygın olarak kullanılmaktadır. $\mathrm{Bu}$ çalışmada da Johansen ve Juselius (1990) tarafından geliştirilen yöntem kullanılmıştır. Johansen ve Juselius tarafından geliştirilen çok değişkenli eş-bütünleşme yöntemi geleneksel yöntemlerle yapılan regresyon analizlerindeki sorunları yok etmek ve araştırmacılara iki yada daha fazla değişken arasındaki ilişkiye dair eşzamanlı modelleri tahmin etmek için maksimum olabilirlik imkanı sunmaktadır (Vazakidis ve Adamopoulos, 2011). Bu analizde değişkenler arasındaki uzun dönemli ilişki, bir zamanlı model yapısı içinde incelenmektedir. Yani bir bütünlük arz etmektedir. Tüm eşbütünleşik ilişkiler bir bütünlük içinde eş zamanlı olarak gözlemlenmektedir. Engle-Granger testinde rastlanabilen belirsizliğe, bu testte rastlanmamaktadır. Johansen Eşbütünleşme Analizi, katsayılar matrisinin en çok benzerlik tahmincilerini ve tutarlı tahminlerini veren bir yöntemdir (Bozkurt ve Dursun, 2006). Aşağıdaki gibi ifade edilir.

$$
Y_{t}=A_{1} Y_{t-1}+A_{2} Y_{t-2}+\cdots \ldots \ldots \ldots+A_{p 1} Y_{t-p}+B X_{1}+\varepsilon_{t}
$$

Burada $Y_{t}$ durağan olmayan I (1) içsel değişkenlerin vektörü; $X_{t}$ dişsal değişkenlerin belirleyici vektörü,ü $A_{1} \ldots . . A_{p}$ ve $B$ tahmin edilecek olan katsayılar matrisi ve $\varepsilon_{t}$ ise hata terimi olarak tanımlanmaktadır. Birçok zaman serisi durağan olmadığı için VAR(Vektor Otoregresif) için kullanılan serilerin genellikle birinci farkı alınarak kullanılmaktadır. Aşağıdaki gibi ifade edilmektir (Murty vd., 2012).

$$
\begin{aligned}
& \Delta \mathrm{Y}_{\mathrm{t}}=\Pi \mathrm{X}_{\mathrm{t}-1}+\sum_{\mathrm{i}=1}^{\mathrm{p}-1} \Gamma_{\mathrm{i}} \Delta \mathrm{Y}_{\mathrm{t}}+\mathrm{BX}_{\mathrm{t}}+\varepsilon_{\mathrm{t}} \ldots \ldots \ldots \ldots \ldots \ldots \ldots \ldots \ldots \ldots \ldots \ldots \ldots \ldots \ldots \ldots \ldots \\
& \text { Burada } \Pi=\sum_{\mathrm{i}=1}^{\mathrm{p}} A_{\mathrm{i}} \text { ve } \Gamma_{\mathrm{i}}=-\sum_{\mathrm{i}=1}^{\mathrm{p}} A_{\mathrm{i}} \text { dir. }
\end{aligned}
$$

Granger'ın temsil kuramı, katsayı matrisi $\Pi$ derece düşürürse yani $r<k$ olursa, her birinin derecesi r olan $\alpha$ ve $\beta$ kxr matrislerinin var olacağını ileri sürer; kaldıki $\pi=\alpha \beta^{\prime}$ ve $\beta^{\prime} Y_{t}$ $\mathrm{I}(0)$ 'dır. $r$ eşbütünleşme ilişkilerinin sayısıdır ve $\beta^{\prime}$ nın her bir kolonu eşbütünleşme vektörüdür. $\alpha$ ise $\Delta Y_{t}^{\prime}$ 'deki ayarlamaların hızını ölçen hata düzeltim parametrelerinin matrisidir. Johansen'in eşbütünleşme testi, Johansen (1988) ve Osterwald Lenum (1992) tarafından belirtildiği gibi, iki sınama istatistiğine yani izleme (trace) sınama istatistiği ile maksimum özdeğer (eigenvalue) sınama istatistiğine dayanır. 
Trace Test İstatistiği: Johansen tarafından geliştirilen $\lambda_{\text {trace }}$ aşağıdaki gibi ifade edilir.

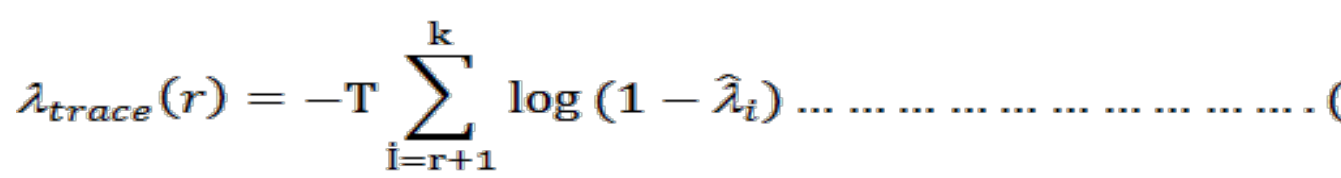

Burada $\hat{\lambda} i, \Pi$ matrisinin i. en geniş özdeğerini, $T$ ise gözlem sayısını ifade etmektedir. Trace testinde sıfır hipotezi, farklı eşbütünleşik bir vektör (ler) sayısından daha az yada bütünleşik ilişkiler ( $\mathrm{r}$ ) sayısına eşit olduğunu gösteren $\mathrm{H}_{0}$ hipotezini test eder. Bu istatistikte karakteristik köklerin değerleri sıfıra yaklaştığında $\lambda_{\text {trace }}$ küçülecektir.

Maksimum Özdeğer (Eigenvalue) Testi: Maksimum Özdeğer (Eigenvalue) testi, koentegre vektörün $\mathrm{r}$ olduğunu ifade eden $\mathrm{H}_{0}$ hipotezini, $\mathrm{r}+1$ olduğunu ifade eden alternatifine karşı test eder. Her iki trace (iz) test istatistiği ile maksimum özdeğer (eigenvalue) istatistiğinin kritik değerleri, Johansen ve Juselius (1990) tarafından verilmiştir. Eğer $\Pi$ matrisinin rankı sıfır olur ise, $T$ matrisini oluşturan değişkenlerin birbirleriyle eşbütünleşik olmadıkları, yani uzun dönemde birlikte hareket etmedikleri sonucuna ulaşılır. Aynı matrisin rankı en az "1" ise, $T$ matrisindeki iki değişkenin uzun dönemde birlikte hareket ettiklerini gösterir (Karamustafa ve Karakaya, 2004).

$$
\lambda_{\max }(r, r+1)=-T \ln \left(1-\hat{\lambda}_{1+r}\right)
$$

Burada $\hat{\lambda} r+1 ;(r+1)$, en büyük ödeğerin karesi ve $T$ ise gözlem sayısını ifade etmektedir.

Aralarında eşbütünleşik ilişki olan iki yada daha fazla değişken için uzun dönemli ilişki aşağıdaki denklem ile ifade edilmektedir. Denklemde $X$ ve $Y$ bağımlı ve bağımsız değişkenleri; $\beta$, değişkenlere ait parametreleri, $\varepsilon$ ise modelin hata terimlerini ifade etmektedir.

$$
\mathrm{B}_{1} \mathrm{X}_{\mathrm{t}}+\mathrm{B}_{2} \mathrm{X}_{\mathrm{t}}+\varepsilon_{\mathrm{t}}=0
$$

Johansen eşbütünleşme vektörünün hata terimleri bir gecikme ile açıklayıcı değişken olarak ifade edildiği aşağıdaki denklem ise, kısa dönem dinamiklerini de dikkate alan uzun dönemli ilişkiyi ortaya koyan “Hata Düzeltme Modeli”ni (ECM) ifade etmektedir.

$$
\Delta \mathrm{X}_{\mathrm{t}}=\alpha_{1} \sum_{\mathrm{I}=1}^{\mathrm{n}} \alpha_{11} \Delta \mathrm{X}_{\mathrm{t}-\mathrm{i}}+\sum_{\mathrm{I}=1}^{\mathrm{m}} \alpha_{12} \Delta \mathrm{X}_{\mathrm{t}-\mathrm{j}}+\alpha \mathrm{Ye}_{\mathrm{t}-1}+\varepsilon_{1 \mathrm{t}} \ldots \text { (11) }
$$

Buradaki (delta) değişkenlerin durağan oldukları seviyelerine ilişkin olarak birinci devresel farkını göstermektedir. Modelde bulunan $\mathrm{X}$, $\mathrm{Y}$ ve $\varepsilon$ değişkenleri, sırasıyla otoregresif eğişken, bağımsız değişkenleri ve $\varepsilon$ ise denklemin hata terimleri serisinin bir gecikmesini ifade etmektedir (Karamustafa ve Karakaya, 2004).

Engle-Granger Eşbütünleşme Testi: Engle-Granger (1987) tarafından geliştirilen bir yöntemdir. Bu yaklaşıma göre, düzeyde durağan olmayan birinci farkı durağan olan zaman 
serileri düzey halleri ile modellenebilmekte ve böylece uzun dönemde meydana gelebilecek olası bilgi kaybı engellenmiş olmaktadır. Ancak bu yaklaşım birden fazla eşbütünleşik vektör olması durumunda geçersiz olmaktadır. Bu noktadan hareketle Johansen (1988)'in geliştirdiği yaklaşımla, tüm değişkenlerin içsel olarak kabul edildikleri VAR modelinden yola çıkılarak, değişkenler arasında kaç tane eşbütünleşik vektörün olduğu test edilebilmektedir. Dolayısıyla, Engle ve Granger (1987) metodunda olduğu gibi, testi tek bir eşbütünleşik vektör beklentisiyle kısıtlamadan, daha gerçekçi bir yöntemle deneme gerçekleştirilebilmektedir (Karagöl vd., 2007).

$$
X_{1, t}=\beta_{1}+\beta_{2, t} X_{2}+\ldots+\beta_{p} X_{p, t}+\varepsilon_{t} \ldots \ldots \ldots \ldots \ldots \ldots \text { (12) }
$$

$\mathrm{p}$, eşitliğe dahil edilen değişken sayısını göstermektedir. Bu regresyon eşitliğinde bütün değişkenlerin $I$ (1) olduğu ve bütün değişkenler arasında sabit bir eşbütünleşme olabileceği varsayılmaktadır. Bundan dolayı kalıntı (residual) eşitliği $\varepsilon_{t}=\beta_{1}-\beta_{2, t} X_{2}-\ldots-\beta_{p} X_{p, t}$ biçimde ifade edilmektedir. Ayrıca Engle-Granger (1987)'a göre değişkenler arasında eşbütünleşmenin bulunması halinde vektör hata düzeltme modeli (VECM) kullanılabilecektir. Oluşturulan VECM, (13), numaralı denklem yardımıyla gösterilebilmektedir.

$$
\mathrm{Y}=\alpha+\Psi_{\mathrm{ec}} \mathrm{c}_{\mathrm{t}-1} \sum_{\mathrm{i}=1}^{\mathrm{k}} \delta \mathrm{ii} \mathrm{Y}_{\mathrm{t}-\mathrm{k}}+\sum_{\mathrm{i}=1}^{\mathrm{k}} \lambda \mathrm{iX}_{\mathrm{t}-\mathrm{k}}+\varepsilon_{\mathrm{t}}
$$

Burada, $\mathrm{ec}_{\mathrm{t}-1}$ hata düzeltme (error correction) terimi, eşbütünleşme ilişkisinden elde edilen bir dönem gecikmeli kalıntıları göstermektedir. Vektör hata düzeltme modeline dayalı olarak ortaya çıkan nedenselliğin kaynağının tespit edilmesi için, bağımsız değişkenlerin bütün katsayılarına beraber uygulanan Wald testine ve hata düzeltme terimlerinin katsayılarına uygulanan $t$ testine bakılması gerekmektedir. Uygulanan Wald testi sonucunda bağımsız değişkenlerin katsayılarının grup olarak $\mathrm{F}$ istatistiğine göre istatistiki olarak anlamlı olması durumunda veya hata düzeltme terimlerinin katsayılarının $t$ istatistiğine göre anlamlı çıkması durumunda veriler arasında nedensellikten bahsedilebilir. Yani VECM, nedenselliğin yönünün tahmin edilmesinde ilave bir alternatif oluşturmaktadır (Demirhan, 2005).

\section{SONUÇ VE TARTIŞMA}

\section{Bulgular}

$\mathrm{Bu}$ çalı̧̧mada ilk olarak yapılan analiz, değişkenlere ait tanımlayıcı istatistiki bilgilerin verilmesinden oluşmaktadır. Daha sonra ise bağımsız değişkenlerin (bankaların sektörler itibariyle kullandırdığı kredi) büyüme (sanayi endeksi) üzerinde herhangi bir etkisinin olup olmadığı panel veri analizi ile test edilmektedir. Tanımlayıcı istatistik sonuçlarına ait değerler Tablo 1’ de görüldüğü gibidir. 
Tablo 1: Tanımlayıcı İstatistikler

\begin{tabular}{|l|c|c|c|c|c|c|c|c|c|c|c|}
\hline Değişkenler & SNYEND & $\mathrm{X} 1$ & $\mathrm{X} 2$ & $\mathrm{X} 3$ & $\mathrm{X} 4$ & $\mathrm{X} 5$ & $\mathrm{X} 6$ & $\mathrm{X} 7$ & $\mathrm{X} 8$ & $\mathrm{X} 9$ & $\mathrm{X} 10$ \\
\hline Ortalama & 10899397 & 10764952 & 28156129 & 9139466. & 13598616 & 8987324. & 9987316. & 47443172 & 12074877 & 8464457. & 7950491. \\
\hline Medyan & 10889500 & 9649826. & 16659013 & 6326674. & 5609246. & 5437072. & 6227692. & 21304396 & 5426092. & 4128742. & 4226874. \\
\hline Maximum & 14130000 & 26906261 & 94714951 & 28118233 & 49412561 & 31186763 & 34672547 & $1.79 \mathrm{E}+08$ & 43111350 & 36099489 & 31607697 \\
\hline Minimum & 8373000. & 1853477. & 1290100. & 1203356. & 1020850. & 635732.7 & 487051.9 & 263083.1 & 416450.1 & 110904.4 & 336106.6 \\
\hline Std. Sapma & 1209391. & 6141070. & 26382386 & 7097958. & 13669281 & 8298697. & 9572007. & 53624754 & 11599061 & 8438273. & 8048365. \\
\hline Skewness & 0.120900 & 0.671478 & 0.722607 & 0.942113 & 1.032808 & 0.945712 & 0.846810 & 0.905274 & 0.966308 & 1.378089 & 1.242029 \\
\hline Kurtosis & 2.498340 & 3.085247 & 2.376226 & 2.860668 & 2.785949 & 2.867332 & 2.479120 & 2.565863 & 2.906160 & 4.284036 & 3.778686 \\
\hline Jarque-Bera & 2.015844 & 11.77018 & 16.10527 & 23.20321 & 28.03181 & 23.36805 & 20.40781 & 22.53261 & 24.33479 & 60.09420 & 44.04982 \\
\hline Olasılık & 0.364977 & 0.002781 & 0.000318 & 0.000009 & 0.000001 & 0.000008 & 0.000037 & 0.000013 & 0.000005 & 0.000000 & 0.000000 \\
\hline Toplam & $1.70 \mathrm{E}+09$ & $1.68 \mathrm{E}+09$ & $4.39 \mathrm{E}+09$ & $1.43 \mathrm{E}+09$ & $2.12 \mathrm{E}+09$ & $1.40 \mathrm{E}+09$ & $1.56 \mathrm{E}+09$ & $7.40 \mathrm{E}+09$ & $1.88 \mathrm{E}+09$ & $1.32 \mathrm{E}+09$ & $1.24 \mathrm{E}+09$ \\
\hline Sum Sq. Dev. & $2.27 \mathrm{E}+14$ & $5.85 \mathrm{E}+15$ & $1.08 \mathrm{E}+17$ & $7.81 \mathrm{E}+15$ & $2.90 \mathrm{E}+16$ & $1.07 \mathrm{E}+16$ & $1.42 \mathrm{E}+16$ & $4.46 \mathrm{E}+17$ & $2.09 \mathrm{E}+16$ & $1.10 \mathrm{E}+16$ & $1.00 \mathrm{E}+16$ \\
\hline Gözlem Say1s1 & 156 & 156 & 156 & 156 & 156 & 156 & 156 & 156 & 156 & 156 & 156 \\
\hline
\end{tabular}

Tablo 1'de çalışmada kullanılan değişkenlere ait tanımlaytıcı istatistikler verilmiştir. $\mathrm{Bu}$ tabloya göre bankalar tarafından kullandırılan krediler içerisinde ilk sırayı X7 (Bireysel Krediler ve Kredi kartları) sektörünün aldığı görülmektedir. Bankaların en çok kredi kullandırdığı sektörlerden ikinci sırayı X4 (İnşaat Sektörü) üçüncü sırayı ise X2 (Toptan ve Perakende Ticareti, Komisyonu ve Motorlu Araçlar Servis Hizmetleri) sektörlerinin aldığ1 görülmektedir. Bankaların kullandırdığı krediler içerisinde ilk sıralarda yer alan sektörlerin kredilerinde de en fazla oynaklığın olduğu yukarıdaki tablodan görülmektedir.

Regresyon analizinde sahte regresyon ilişkisinin olmaması için verilere ait sağlamlık testlerinin yapılmış ve gerekli koşulların sağlanmış olması gerekmektedir. Yani bağımlı değişken ile ve bağımsız değişkenler arasında şu dört koşulun oluşması gerekir.

1- Serilerin durağan olması gerekir.

2-Değişkenler arasında korelasyon olmaması gerekir.

3- Değişkenler arasında değişen varyans sorununun olmaması gerekir.

4- Serilerin normal dağılması gerekir.

$\mathrm{Bu}$ çalışmada da bağımlı değişken ile bağımsız değikenler arasında sağlamlık testi yapıldıktan sonra bağımlı ve bağımsız değişkenler arasındaki kısa ve uzun dönemli ilişkilere bakılmıştır. Sağlamlık testleri ve sonuçları aşağıda sırası ile verilmiştir.

ADF testinde ( sabitli, sabitli ve trendli) zaman serilerinde durağanlık, zaman içerisinde ortalamanın ve varyansın sabit olması ve gecikmeli iki zaman periyodundaki değişkenlerin ko-varyansının değişkenler arasındaki gecikmeye bağlı olup olmaması olarak tanımlanmaktadır (Gujarati, 2010: 713).

Ortalama: $E Y_{t}=\mu$

Varyans: $\operatorname{var}_{t}=\mathrm{E}\left(\mathrm{Y}_{\mathrm{t}}-\mu\right)^{2}=\sigma^{2}$

Ortak Varyans: $\gamma_{k}=E\left[\left(Y_{t}-\mu\right)\left(Y_{t+k}-\mu\right)\right]$ 
Burada, $\gamma_{k}, k$ gecikme ile ortak varyans (yada ardışık ortak varyans), $Y_{t}$ ile $Y_{t+k}$ arasındaki, yani aralarında $k$ dönem fark olan iki $Y$ arasındaki ortak varyandır. Eğer $k=0$ ise $\gamma_{0}$ bulunur ki bu da $Y^{\prime}$ nin Varyansıdır $\left(=\sigma^{2}\right) ; k=1$ ise, $\gamma_{1}, Y^{\prime}$ nin ardışık iki değeri arasındaki ortak varyansıdır.

Analiz için kullanılan verilerde durağanlığın olmaması yapılan çalışmada sahte regresyonun oluşmasına neden olabilir. Zaman serilerinde kullanılan bağımlı ve bağımsız değişkenler durağan değillerse veriler stokastik ve deterministik trend içermektedirler. Verilere ait ADF birim kök testi sonuçları Tablo 2'de görüldüğü gibidir.

Tablo 2: ADF Birim Kök Testi

\begin{tabular}{|c|c|c|c|c|}
\hline \multirow[b]{2}{*}{ Değişkenler } & \multicolumn{2}{|c|}{ ADF (Sabitli) } & \multicolumn{2}{|c|}{ ADF (Sabitli ve Trendli) } \\
\hline & Düzey & 1. Fark & Düzey & 1. Fark \\
\hline Sanayi Endeksi & $-2.96(0.0403)^{* *}$ & $-3.21(0.020)^{* *}$ & $-4.12(0.0074)^{*}$ & $-3.22(0.084)^{*}$ \\
\hline $\mathrm{X} 1$ & $2.74(1.000)$ & $-10.39(0.000)^{* * *}$ & $0.69(0.999)$ & $-10.72(0.000)^{* * *}$ \\
\hline $\mathrm{X} 2$ & 1.88 (0.999) & $-2.86(0.0489)^{* *}$ & $-0.76(0.965)$ & $-3.75(0.021)^{* *}$ \\
\hline $\mathrm{X3}$ & $4.87(1.000)$ & $-10.36(0.000)^{* * *}$ & $1.41(1.000)$ & $-11.57(0.000)^{* * *}$ \\
\hline$\overline{\mathrm{X} 4}$ & $6.64(1.000)$ & $-4.39(0.005)^{* * *}$ & $1.46(1.000)$ & $-11.16(0.000)^{* * *}$ \\
\hline $\mathrm{X} 5$ & $4.35(1.000)$ & $-10.48(0.000)^{* * *}$ & $0.64(0.999)$ & $-11.56(0.000)^{* * *}$ \\
\hline$\overline{\mathrm{X} 6}$ & $5.01(1.000)$ & $-12.76(0.000)^{* * *}$ & $0.53(0,999)$ & $-14.75(0.000)^{* * *}$ \\
\hline $\mathrm{X} 7$ & 7.39(1.000) & $-3.35(0.013)^{* *}$ & $0.53(0.999)$ & $-5.23(0.001)^{* * *}$ \\
\hline $\mathrm{X} 8$ & $3.50(1.000)$ & $-12.30(0.000)^{* * *}$ & $0.41(0.999)$ & $-13.56(0.000)^{* * *}$ \\
\hline X9 & $5.25(1.000)$ & $-3.32(0.015)^{* *}$ & $2.67(1.000)$ & $-12.23(0.000)^{* * *}$ \\
\hline $\mathrm{X} 10$ & $4.70(1.000)$ & $-4.49(0.000)^{* * *}$ & $1.55(1.000)$ & $-5.37(0.000)^{* * *}$ \\
\hline
\end{tabular}

Değişkenler arasında kısa ve uzun dönemli ilşkilere bakılabilmesi için verilerin düzeyde durağan değilde birinci farklarında durağan olması istenir. Tablo 2'den de görüldüğü üzere sadece sanayi endeksi düzeyde durağan çıkmış (bunun da \% 5'e çok yakın olması çalışmalarda sıkıntı oluşturmayacağı söylenmektedir), diğer tüm değişkenlerin hepsi birinci farklarında durağanlaşmıştır.

Analizde kullanılan bağımsız değişkenler arasında korelasyon ve değișen varyans sorununun olup/olmadığını tespit etmek için Breusch-Godfrey Serial Correlation LM Test’i kullanılmıştır. Hipotezler ise şu şekilde geliştirilmiştir.

$\mathrm{H} 0=$ Seriler arasında korelasyon yoktur.

$\mathrm{H} 0=$ Seriler arasında değişen varyans (heteroskedastisi) sorunu yoktur. 
Tablo 3: Korelasyon ve Heteroskedastisiti Sonuçları

\begin{tabular}{|l|c|l|r|}
\hline \multicolumn{4}{|c|}{ Breusch-Godfrey Serial Correlation LM Test: } \\
\hline F-statistic & 0.989172 & Prob. F(2,141) & 0.3744 \\
\hline Obs*R-squared & 2.144685 & Prob. Chi-Square(2) & $\mathbf{0 . 3 4 2 2}$ \\
\hline \multicolumn{3}{|c|}{ Heteroskedasticity Test: Breusch-Pagan-Godfrey } \\
\hline F-statistic & 1.050403 & Prob. F(11,143) & 0.4059 \\
\hline Obs*R-squared & 11.58774 & Prob. Chi-Square(11) & $\mathbf{0 . 3 9 5 4}$ \\
\hline Scaled explained SS & 26.01392 & Prob. Chi-Square(11) & 0.0065 \\
\hline
\end{tabular}

Çalışmada kullanılan bağımısız değişkenlerin bir gecikmesi alınarak korelasyon analizi yapıldığında Prob. Chi-Square(2) değerinin 0, 3422 çıkdığı görülmektedir. Bilimsel çalışmalarda bu oranın \%5'in üzerinde olması istenir. Bu durumda geliştirilen hipotezlerden H0 kabul edilirken H1 hipotezi reddedilir. Yine Tablo 3'te heteroskedastisiti (değişen varyans) sonuçlarına bakıldığında Prob. Chi-Square(11) değerinin 0.3954 çıkmış olması verilerin homoskedastik olduğunu yani değişen varyans sorununun olmadığını göstermektedir. Bilimsel çalışmalarda bu oranın \%5 'in üzerinde olması istenmektedir. Çıkan sonuçta \%5in üzerinde olduğu için $\mathrm{H} 0$ hipotezi kabul edilirken $\mathrm{H} 1$ hipotezi reddedilmiştir.

$\mathrm{H} 0=$ Veriler normal dağılmıştır

Grafik 1: Veriler Arasındaki Dağılım

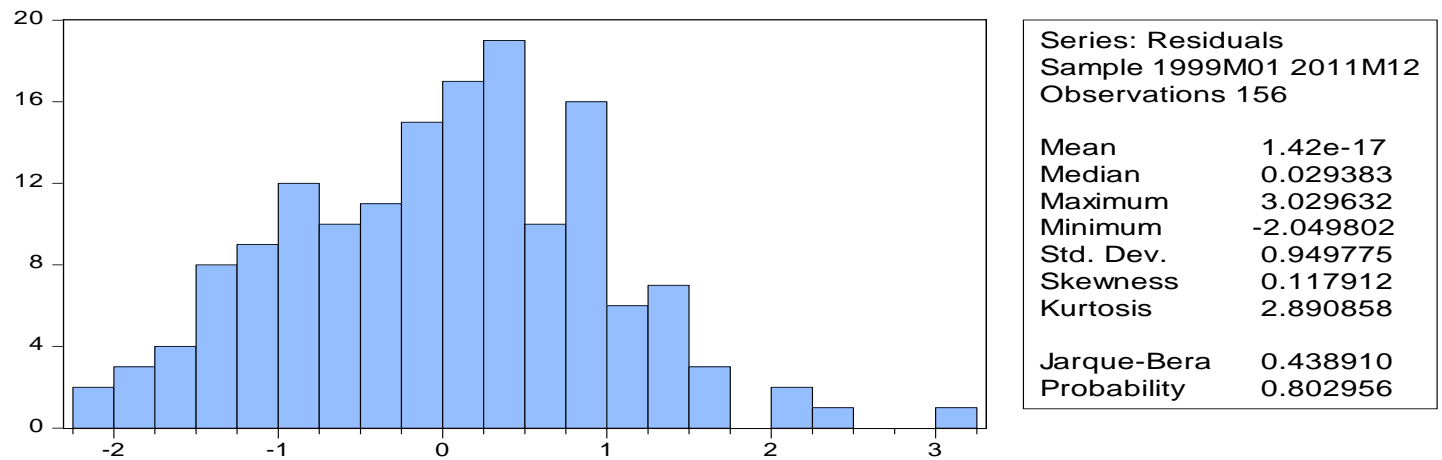

Çoklu regresyon analizinde sahte regresyon ilişkisinin olmaması için analizde kullanılan değişkenlere ait zaman serisi verilerinin normal dağılım göstermesi gerekir. Analizde kullanılan bir verinin normal dağılıp/dağılmadığını anlamak için Jarque-Bera Prob. değerine bakılmaktadır. Bu değer \%5'in üzerinde ise veriler normal dağılmaktadır. Şayet $\% 5$ 'in altında ise veriler normal dağılmamaktadır. $\mathrm{Bu}$ çalışmanın analizinde kullanılan verilerin, normal dağılan rassal serileri oluşturulduktan sonraki dağılım sonuçlarına bakıldığında Jarque-Bera Prob. değerinin 0,802956 olduğu görülmektedir. Bu değer \%5'den daha büyük olduğu için normal dağılan rassal serilere ait verilerin itanilen kriterleri sağladığ1 görülmektedir. Sonuçlara göer H0 hipotezi kabul edilirken H1 hipotezi reddedilmiştir. 
Yukarıda belirtilen sağlamlık testlerinde gerekli koşullar sağlandıktan sonra seriler arasındaki kısa ve uzun dönemli ilişkiler tespitine geçilmiştir. Seriler arasında yukarıda belirtilen koşullar sağlanmamış olsaydı, kısa ve uzun dönemde elde edilen ilişsiler arasında sahte (yanıltıcı) ilişkilerin olduğu söylenebilirdi. Seriler arasındaki kısa ve uzun dönemli ilişkilerin sonuçları ve yorumları aşağıda verilmiştir.

Tablo 4: Wald Testi Sonuçları

\begin{tabular}{|l|c|c|c|}
\hline \multicolumn{4}{|l|}{ Wald Test: } \\
\hline Test Statistic & Value & df & Probability \\
\hline F-statistic & 1.061692 & $(2,131)$ & 0.3488 \\
\hline Chi-square & 2.123384 & 2 & 0.3459 \\
\hline
\end{tabular}

Wald testi bağımlı değişken ile açıklayıcı değişkenler arasında kısa dönemli bir ilişkinin olup/olmadığını tespit etmek amacı ile kullanılmaktadır. Bu testin Prob. değerinin \%5’den küçük olması, bağımsız değişkenlerden açıklayıcı değişkenlere doğru kısa dönemli bir ilişkinin olduğunu gösterir. Bu çalışmanın Wald test değeri Tablo 4'ten de görüldüğü gibi Prob. değeri 0,3459 çıkmıştır. Sonuç \%5'den daha büyüktür. Bu durum, çalışmada kullanılan bağımsız değişkenden açıklayıcı değişkenlere doğru kısa vadeli herhangi bir ilişkinin bulunmadığını göstermektedir.

Tablo 5 : Johansen Eş Bütünleşme Testi

\begin{tabular}{|l|c|c|c|c|}
\hline \multicolumn{5}{|c|}{ Serbest Eşbütünleşme SıralamaTesti (Trace) } \\
\hline $\begin{array}{c}\text { Hypothesized } \\
\text { No. of CE(s) }\end{array}$ & Özdeğer & İz İstatistiği & $\begin{array}{c}\mathbf{0 . 0 5} \\
\text { Kritik Değer }\end{array}$ & Prob.** \\
\hline None * & 0.451107 & $\mathbf{3 6 6 . 3 9 7 2}$ & $\mathbf{2 8 5 . 1 4 2 5}$ & $\mathbf{0 . 0 0 0 0}$ \\
\hline At most 1 * & 0.320636 & $\mathbf{2 7 4 . 6 2 0 0}$ & $\mathbf{2 3 9 . 2 3 5 4}$ & $\mathbf{0 . 0 0 0 4}$ \\
\hline At most 2 * & 0.313332 & $\mathbf{2 1 5 . 4 7 0 4}$ & $\mathbf{1 9 7 . 3 7 0 9}$ & $\mathbf{0 . 0 0 4 5}$ \\
\hline At most 3 & 0.249706 & 157.9572 & 159.5297 & 0.0607 \\
\hline At most 4 & 0.204535 & 114.0018 & 125.6154 & 0.2048 \\
\hline At most 5 & 0.173922 & 78.99111 & 95.75366 & 0.3989 \\
\hline At most 6 & 0.112226 & 49.75791 & 69.81889 & 0.6483 \\
\hline At most 7 & 0.088595 & 31.54517 & 47.85613 & 0.6371 \\
\hline At most 8 & 0.063806 & 17.35172 & 29.79707 & 0.5471 \\
\hline At most 9 & 0.046117 & 7.263995 & 15.49471 & 0.8409 \\
\hline At most 10 & 0.000263 & 0.040270 & 3.841466 & \\
\hline & Serbest Eşbütünleşme SıralamaTesti (Maximum Eigenvalue) & \\
\hline
\end{tabular}




\begin{tabular}{|l|c|c|c|c|}
\hline $\begin{array}{c}\text { Hypothesized } \\
\text { No. of CE(s) }\end{array}$ & Özdeğer & $\begin{array}{c}\text { Max-Eigen } \\
\text { İstatistiği }\end{array}$ & $\begin{array}{c}\mathbf{0 . 0 5} \\
\text { Critical Value }\end{array}$ & Prob.** \\
\hline None $*$ & 0.451107 & $\mathbf{9 1 . 7 7 7 2 1}$ & $\mathbf{7 0 . 5 3 5 1 3}$ & $\mathbf{0 . 0 0 0 2}$ \\
\hline At most 1 & 0.320636 & 59.14955 & 64.50472 & 0.1479 \\
\hline At most 2 & 0.313332 & 57.51327 & 58.43354 & 0.0615 \\
\hline At most 3 & 0.249706 & 43.95538 & 52.36261 & 0.2778 \\
\hline At most 4 & 0.204535 & 35.01069 & 46.23142 & 0.4593 \\
\hline At most 5 & 0.173922 & 29.23320 & 40.07757 & 0.8667 \\
\hline At most 6 & 0.112226 & 18.21275 & 33.87687 & 0.7364 \\
\hline At most 7 & 0.088595 & 14.19344 & 27.58434 & 0.4630 \\
\hline At most 8 & 0.063806 & 10.08773 & 21.13162 & 0.8409 \\
\hline At most 9 & 0.046117 & 7.223726 & 14.26460 & 3.841466 \\
\hline At most 10 & 0.000263 & 0.040270 & & 0.4753 \\
\hline
\end{tabular}

Tablo 5'ten de görüldüğü üzere hem Trace (iz) testi sonucuna göre hem de Maksimum Özdeğer (Maximum Eigenvalue) sonucuna göre Prob. değerleri içerisinde \%5'den daha düşük değerler bulunduğundan dolayı analizde kullanılan bağımlı değişken ile bağımsız değişkenler arasında en az bir eş bütünleşik durumun olduğunu göstermektedir. Bundan dolayı H0 hipotezi olan, seriler arasında eşbütünleşmenin olmadığı ifadesi red edilirken, alternatif H1 hipotezi kabul edilmiştir. Yani bağımlı değişken ile bağımsız değişkenler arasında eşbütünleşmenin olduğu kabul edilmektedir. Çıkan sonuçlar içerisinde hem iz istatistiği testi hem de maksimum özdeğer testi içerisinde $\% 5$ kritik değerden daha büyük değerler bulunduğu için, bağımsız değişkenlerden bağımlı değişkene doğru uzun dönemli, pozitif yönlü bir ilişkinin olduğu görülmektedir.

Tablo 6: Hata Düzeltme Testi Sonuçları

\begin{tabular}{|l|c|c|c|c|}
\hline \multicolumn{1}{|c|}{ Değişkenler } & Katsayılar & Std. Hata & t-İsatatistiği & Olasılıklar \\
\hline LOGX1 & 0.419034 & 0.112892 & 3.711830 & 0.0003 \\
\hline LOGX2 & 0.219112 & 0.058238 & 3.762391 & 0.0002 \\
\hline LOGX3 & 0.009946 & 0.117165 & 0.084892 & 0.9325 \\
\hline LOGX4 & -0.255753 & 0.086030 & -2.972818 & 0.0035 \\
\hline LOGX5 & $3.04 \mathrm{E}-09$ & $3.94 \mathrm{E}-09$ & 0.771009 & 0.4420 \\
\hline LOGX6 & -0.009397 & 0.087620 & -0.107245 & 0.9147 \\
\hline LOGX7 & -0.005566 & 0.036807 & -0.151222 & 0.8800 \\
\hline LOGX8 & 0.008300 & 0.065391 & 0.126929 & 0.8992 \\
\hline LOGX9 & -0.124093 & 0.034638 & -3.582517 & 0.0005 \\
\hline LOGX10 & 0.001129 & 0.055957 & 0.020170 & 0.9839 \\
\hline
\end{tabular}




\begin{tabular}{|l|l|l|l|c|}
\hline RESID02(-1) & $\mathbf{- 0 . 4 1 9 6 1 4}$ & $\mathbf{0 . 0 6 3 2 0 2}$ & $\mathbf{- 6 . 6 3 9 2 9 5}$ & $\mathbf{0 . 0 0 0 0}$ \\
\hline C & 0.313395 & 1.349693 & 0.232197 & 0.8167 \\
\hline R-squared & 0.764731 & \multicolumn{2}{|l|}{ Mean dependent var } & 4.785015 \\
\hline Adjusted R-squared & 0.746506 & \multicolumn{2}{|l|}{ S.D. dependent var } & 0.165060 \\
\hline S.E. of regression & 0.083105 & Akaike info criterion & -2.062706 \\
\hline Sum squared resid & 0.980714 & \multicolumn{2}{|l|}{ Schwarz criterion } & -1.826061 \\
\hline Log likelihood & 170.8284 & Hannan-Quinn criter. & -1.966581 \\
\hline F-statistic & 41.96040 & Durbin-Watson stat & & 1.804482 \\
\hline Prob(F-statistic) & 0.000000 & & \\
\hline
\end{tabular}

Hata düzeltme testinin yapılmasının nedeni veriler arasında uzun dönemli ilişki tespit edilirken verilerin farkları alınarak analize dahil edilmektedir. $\mathrm{Bu}$ durumunda verilerin farkları alınarak analiz yapıldığında uzun dönemde verilerde değer kaybı oluşabilmektedir. $\mathrm{Bu}$ değer kayıpları da yapılan analizin sonuçlarına olumsuz etki yapabilmektedir. Bu olumsuz etkileri, dengesizlikleri ortadan kaldırmak için hata düzeltme modelleri oluşturulmaktadır. Hata düzeltme modelleri ile de bu farklar ortadan kaldırılmaktadır. Tablo 6'ya bakıldığında, Resid02(-1) katsayı değerinin (-0,419614) çıkmış olması, önceki dönemlerde oluşan dengesizliğin yada veri kaybının, bir sonraki dönemde yaklaşık \%42'sinin düzeldiği görülmektedir.

Tablo 7: Engle-Granger Eşbütünleşme Testi

\begin{tabular}{|c|c|c|c|}
\hline & & t-Statistic & Prob.* \\
\hline \multicolumn{2}{|c|}{ Augmented Dickey-Fuller test statistic } & -15.10655 & 0.0000 \\
\hline \multirow[t]{3}{*}{ Test critical values: } & \multirow{3}{*}{$\begin{array}{c}\text { 1\% level } \\
5 \% \text { level } \\
10 \% \text { level }\end{array}$} & -3.473096 & \\
\hline & & -2.880211 & \\
\hline & & -2.576805 & \\
\hline
\end{tabular}

Engle-Granger eşbütünleşme testinde, verilerin birinci farkları alındıktan sonraki değerlerinde durağanlık sağlandıktan sonraki kalıntı (resid) değerlerinin de düzeyde durağan olması gerekmektedir. Eğer verilerde bu koşul sağlanır ise bu durumda bağımlı ve bağımsız değişkenler arasında uzun dönemli bir dengenin olduğundan bahsedilebilir. Bu çalışmada da Angle-Granger eşbütünleşme sonuçlarına bakıldığında yukarıda belirtilen koşulların sağlandığı görülmektedir. Çünkü birinci farklarından sonra durağan hale gelen kalıntı (resid) değerlerinin birim kök sınaması sonuçlarının düzeyde durağan olduğu Tablo 7'den görülmektedir. Bu durumda bankaların sektörler bazında kullandırdığı krediler içersinde ilk on sırayı alan sektörler ile ekonomik büyüme arasında uzun dönemli bir dengenin olduğunu söylemek mümkündür. 
Yukarıdaki işlemler sonucu verilerin regrese edilebilir hale getirilmesi ile birlikte bağımlı değişken ve bağımsız değişkenler arasındaki ilişki Tablo 8'de verilmişitir.

Tablo 8: Çoklu Regresyon Sonuçları

\begin{tabular}{|l|c|c|c|c|}
\hline Bağıml Değişken: LOGSNYEND \\
\hline Değeişkenler & Katsay1lar & Std. Hata & t-İstatistiği & Olasılıklar \\
\hline LOGX1 & 0.399230 & 0.125222 & 3.188164 & $\mathbf{0 . 0 0 1 8}$ \\
\hline LOGX2 & 0.218453 & 0.063566 & 3.436626 & $\mathbf{0 . 0 0 0 8}$ \\
\hline LOGX3 & 0.071760 & 0.129460 & 0.554303 & 0.5802 \\
\hline LOGX4 & -0.284218 & 0.095975 & -2.961374 & $\mathbf{0 . 0 0 3 6}$ \\
\hline LOGX5 & $1.69 E-09$ & 4.20 E-09 & 0.402657 & 0.6878 \\
\hline LOGX6 & -0.006613 & 0.096828 & -0.068292 & 0.9456 \\
\hline LOGX7 & -0.013839 & 0.038115 & -0.363074 & 0.7171 \\
\hline LOGX8 & 0.007327 & 0.072767 & 0.100695 & 0.9199 \\
\hline LOGX9 & -0.128165 & 0.038103 & -3.363651 & $\mathbf{0 . 0 0 1 0}$ \\
\hline LOGX10 & 0.023520 & 0.062137 & 0.378516 & 0.7056 \\
\hline C & -0.040388 & 1.417754 & -0.028488 & 0.9773 \\
\hline R-squared & $\mathbf{0 . 7 1 3 3 1 0}$ & Mean dependent var & 4.780800 \\
\hline Adjusted R-squared & 0.693538 & S.D. dependent var & 0.168170 \\
\hline S.E. of regression & 0.093097 & Akaike info criterion & -1.842445 \\
\hline Sum squared resid & 1.256724 & Schwarz criterion & -1.627391 \\
\hline Log likelihood & 154.7107 & Hannan-Quinn criter. & -1.755099 \\
\hline F-statistic & 36.07726 & Durbin-Watson stat & 1.804482 \\
\hline Prob(F-statistic) & $\mathbf{0 . 0 0 0 0 0 0}$ & & & \\
\hline
\end{tabular}

Tablo 8'den de görüldüğü gibi R2'nin $\quad 0.713310$ (\%60'1n üzerinde olması istenir) olması araştırmaya konu olan bağımlı değişken ile bağımsız değişkenler arasında ilişkiye bakılabileceğini göstermektedir. R2'nin 0.713310 çıkmış olması anlizde kullanılan bağımsız değişkenlerin bağımlı değişkeni açıklamada yeterli olduğunu göstermektedir. Doğal logaritmaları alınmış bağımsız değişkenlerin olasılık (Prob) değerlerine bakıldığında ise, Türkiye'de bankaların sektörler bazında kullandırdığı kredilerde ilk 10 içerisinde yer alan sektörler içersinde büyüme üzerinde uzun dönemde pozitif yönlü anlamlı etkiye LOGX1 (tekstil ve tekstil ürünleri sanayi), LOGX2 (toptan ve perakende ticareti, komisyonu ve motorlu araçlar servis hizmeti), LOGX4 (inşaat sektörü) ve LOGX9 (elektrik, gaz ve su kaynakları) sahip oldukları görülmektedir. Çünkü bunların olasılık değerlerinin $<\% 5$ 'den daha düşüktür. Bankalar tarafından kullandırılan krediler içerisinde ilk onda yer almasına rağmen LOGX3, LOGX5, LOGX6, LOGX7, LOGX8, ve LOGX10'un büyüme üzerinde 
anlamlı bir etkiye sahip olmadıkları görülmektedir. Ayrıca seriler arasında dört bağımsız değişkenin bağımlı değişken üzerinde anlamlı ve pozitif etkiye sahip olması seriler arasında çoklu doğrusallığın da olduğunu göstermektedir. Prob(F-statistic) 0.000000 , yani $<\% 5$ olmas 1 F-istatistiğinin anlamlı olduğunu göstermektedir. Yani bankaların sektörler bazında kullandırdığı kredilerin büyüme üzerinde genel olarak ortaklaşa etkiye sahip olduğunu göstermektedir.

Analizde kullanılan bağımlı ve bağımsız değişkenler arasındaki nedenseliği tespit etmek amacı ile “Granger Nedenselliği”ne bakılmış, sonuçlar Tablo 9' da verilmiştir.

Tablo 9: Granger Nedensellik Test Sonuçları

\begin{tabular}{|c|c|c|c|c|}
\hline Sıfır Hipotezi: & Obs & F-Statistic & Prob. & Nedensellik \\
\hline LOGX1 does not Granger Cause LOGSNYEND & 155 & 7.31646 & $0.0076 * * *$ & Var \\
\hline LOGX2 does not Granger Cause LOGSNYEND & 155 & 8.74238 & $0.0036^{* * *}$ & Var \\
\hline LOGX3 does not Granger Cause LOGSNYEND & 155 & 6.05719 & $0.0150^{* *}$ & Var \\
\hline LOGX4 does not Granger Cause LOGSNYEND & 155 & 4.65701 & $0.0325^{* *}$ & Var \\
\hline LOGX6 does not Granger Cause LOGSNYEND & 155 & 7.58561 & $0.0066^{* * *}$ & Var \\
\hline LOGX7 does not Granger Cause LOGSNYEND & 155 & 11.0827 & $0.0011^{* * *}$ & Var \\
\hline LOGX8 does not Granger Cause LOGSNYEND & 155 & 6.05248 & $0.0150^{* *}$ & Var \\
\hline LOGX9 does not Granger Cause LOGSNYEND & 155 & 4.92542 & $0.0279 * *$ & Var \\
\hline LOGX10 does not Granger Cause LOGSNYEND & 155 & 5.25072 & $0.0233 * *$ & Var \\
\hline LOGSNYEND does not Granger Cause LOGX10 & 155 & 4.06750 & $0.0455^{* *}$ & Var \\
\hline LOGX10 does not Granger Cause LOGX1 & 155 & 6.48036 & $0.0119 * *$ & Var \\
\hline LOGX2 does not Granger Cause LOGX4 & 155 & 3.92274 & $0.0494 * *$ & Var \\
\hline LOGX2 does not Granger Cause LOGX6 & 155 & 8.06320 & $0.0051^{* * *}$ & Var \\
\hline LOGX2 does not Granger Cause LOGX8 & 155 & 7.81504 & $0.0059 * * *$ & Var \\
\hline LOGX2 does not Granger Cause LOGX10 & 155 & 7.19118 & $0.0081^{* * *}$ & Var \\
\hline LOGX4 does not Granger Cause LOGX3 & 155 & 7.33551 & $0.0075^{* * *}$ & Var \\
\hline LOGX6 does not Granger Cause LOGX3 & 155 & 4.19076 & $0.0424 * *$ & Var \\
\hline LOGX7 does not Granger Cause LOGX3 & 155 & 4.17550 & $0.0427 * *$ & Var \\
\hline LOGX3 does not Granger Cause LOGX8 & 155 & 6.72028 & $0.0105^{* *}$ & Var \\
\hline LOGX10 does not Granger Cause LOGX3 & 155 & 6.65612 & $0.0108 * *$ & Var \\
\hline LOGX7 does not Granger Cause LOGX4 & 155 & 5.20662 & $0.0239 * *$ & Var \\
\hline LOGX4 does not Granger Cause LOGX8 & 155 & 5.19834 & $0.0240^{* *}$ & Var \\
\hline LOGX4 does not Granger Cause LOGX10 & 155 & 6.26629 & $0.0134 * *$ & Var \\
\hline LOGX5 does not Granger Cause LOGX10 & 155 & 3.39892 & $0.0672 * *$ & Var \\
\hline LOGX7 does not Granger Cause LOGX6 & 155 & 6.84450 & $0.0098^{* * *}$ & Var \\
\hline LOGX6 does not Granger Cause LOGX7 & 155 & 4.06656 & $0.0455^{* *}$ & Var \\
\hline LOGX6 does not Granger Cause LOGX8 & 155 & 5.47702 & $0.0206^{* *}$ & Var \\
\hline LOGX10 does not Granger Cause LOGX6 & 155 & 5.10329 & $0.0253^{* *}$ & Var \\
\hline LOGX6 does not Granger Cause LOGX10 & 155 & 5.90415 & $0.0163^{* *}$ & Var \\
\hline LOGX8 does not Granger Cause LOGX9 & 155 & 4.38853 & $0.0378^{* *}$ & Var \\
\hline LOGX10 does not Granger Cause LOGX8 & 155 & 7.22825 & $0.0080 * * *$ & Var \\
\hline LOGX10 does not Granger Cause LOGX9 & 155 & 4.69476 & $0.0318^{* *}$ & Var \\
\hline
\end{tabular}

*** Değişkenlerin \%1 anlamlılık düzeyinde birbirlerinin granger nedeni olduğunu göstermektedir.

** Değişkenlerin \%5 anlamlılık düzeyinde birbirlerinin granger nedeni olduğunu göstermektedir.

Granger nedensellik testine dair sonuçlar Tablo 9'dan da görüldüğü üzere bağımsız değişkenlerden bağımlı değişken doğru \%1 ve \%5 anlamlılık düzeyinde bir nedenselliğin olduğu görülürken, yine bağımsız değişkenlerin de kendi içerisinde nedenselliğin var olduğu ilgili tablodan görülmektedir. Bağımlı değişkenden bağımısız değişkenlere doğru 
nedenselliğe bakıldığında ise yalnızca X10 bağımsız değişkenine doğru nedenselliğin olduğu görülmektedir.

\section{Sonuç}

Bu çalışmada 1999-2011 yılları arasında Türkiye'deki bankaların sektörler bazında kullandırmış olduğu kredilerden ilk on içerisinde yer alanlar ile ekonomik büyüme arasındaki ilişki panel veri yöntemi ile test edilmiştir. Yapılan analizler sonucuna göre, bankaların sektörlere kullandırdığı kredi ile ekonomik büyüme arasında uzun dönemli, istikrarlı bir ilişkinin olduğu tespit edilmiştir. Bankaların ilk on içerisinde yer alan sektörlere kullandırdığ kredilerin, hem Johansen eşbütünleşme testi sonuçlarına göre hem de Engle-Granger testi sonuçlarına göre uzun dönemde ekonomik büyümeyi olumlu yönde etkilediği tespit edilmiştir. Bu sonuçlar bu alanda yapılan çalışmalardan, King and Levine (1993), Levine (1997), Luintel and Khan (1999), Güven (2002), Khan ve diğ. (2005), Ghirmay (2005) ve Yılmazkuday (2011) ile paralellik göstermektedir. Bankaların sektörler bazında kullandırdığı kredilerden ilk on içerisinde yer alanlar ile ekonomik büyüme arasında kısa dönemde herhangi bir ilişkinin olmadığı tespit edilmiştir.

Tablo 8'deki Prob(F-statistic) değerinin 0.000000 çıkmış olması, bankaların sektörler bazında kullandırdığı kredilerin bir bütün olarak ekonomik büyüme üzerinde pozitif yönlü etkiye sahip olduğunu göstermektedir. Yine aynı tabloda yer alan bağımsız değişkenlerden ekonomik büyüme üzerinde en fazla pozitif etkiye sahip olan sektörlerin başında ise "Tekstil ve Tekstil Ürünleri Sanayi, Toptan ve Perakende Ticareti, Komisyonu ve Motorlu Araçlar Servis Hizmeti, İnşaat Sektörü, Elektrik, Gaz ve Su Kaynakları” geldiği görülmektedir. Bu çalışmadan elde edilen sonuçlara göre hükümetlerin, büyümeye dönük politikalarını etkinleştirmek istemeleri durumunda bankalar kanalıyla yukarıda belirtilen sektörlere dönük kredi kullanımını artırmaları durumunda, ekonomik büyümenin daha fazla olabileceğini söylemek mümkündür.

\section{KAYNAKLAR}

Ahmed, A. D., (2008), "Financial Liberalization, Financial Development and Growth in SubSaharan Africa's Economics Reform: An Empirical Investigation”, Centre for Strategic Economic Studies, Victoria University, Australia.

Aghion, P.; Howitt, P., ve Mayer-Foulkes, D., (2005), “The effect of Financial Development on Convergence: Theory and Evidence”, Quarterly Journal of Economics, 120 (1), ss.173-222.

Beck, T. ve Levine, R., (2004), "Stock Markets, Banks, and Growth: Panel Evidence", Journal of Banking \& Finance, 28, ss.423-442.

Bozkurt, H. ve Dursun, G., (2006), "Bilgi Ve İletişim Teknolojileri İle Yabancı Doğrudan Yatırım Akımları Arasındaki Etkileşim: Türkiye İçin Kointegrasyon Analizi, 19802004”, Bilgi Ekonomisi ve Yönetimi Dergisi, Cilt I-I ve I-II, ss.37-50. 
Calderŏn, C. ve Liu, L., (2002), “The Direction of Causality Between Financial Development and Economic Growth”, Central Bank of Chile, Working Papers No:184.

Ceylan, S. ve Durakaya, M., (2010), "Türkiye'de Kredi Kulanımı ve Büyüme İlişkisi”, Atatürk Üniversitesi İktisadi ve İdari Bilimler Dergisi, Cilt: 24, Sayı: 2, ss.21-35.

De Gregorio, J. ve Guidotti, P. E., (1995), "Financial Development and Economic Growth”, World Development, 23 (3), ss.433-448.

Demetriades O. P. ve Hussein, A. K., (1996), "Does Financial Development cause Economic Growth? Time Series evidence from 16 countries", Journal of Development Economics, vol. 51, Issue 2, ss.387-411.

Demirhan, E., (2005), "Büyüme Ve İhracat Arasındaki Nedensellik İlişkisi: Türkiye Örneği”, Ankara Üniversitesi SBF Dergisi, 60 (4), ss.75-88.

Dickey, D.A. ve Fuller, W.A. (1981), "The Likelihood Ratio Statistics for Autoregressive Time Series with a Unit Root”, Econometrica 49, ss.1057-72.

Erem, I., (2013), "Sermaye Yapısına Etki Eden Faktörlerin Belirlenmesi: Türk Bankacılık Sektörü Örneği”, 17. Finans Sempozyumu, 23-26 Ekim, ss.329-339, Muğla.

Ghirmay, T. (2005), "Financial Development and Economic Growth in Sub- Saharan African Countries: Evidence from Time Series Analysis”, African Development Review, 16 (3), ss.415-432.

Güven, S., (2002), “Türkiye'de Banka Kredileri ve Büyüme İlişkisi”, İktisat İşletme ve Finans İnceleme-Araştırma dergisi, Ağustos, ss.88-100.

Hassan, M.K.; Sanchez, B ve Yu, SJ., (2011), "Financial Development and Economic Growth: New Evidence From Panel Data”, The Quarterly Review of Economic and Finance, 51, ss.88-104.

Jalilian, H. ve Kirkpatrick, C., (2002), "Financial Development and Poverty Reduction in Developing Countries”, International Journal of Finance and Economics, 7, ss.97-108.

Johansen, S., (1988), "Statistical and hypothesis Testing of Cointegration Vectors", Journal of Economic Dynamics and Control”, 12, ss.231-54. http://ideas.repec.org/a/eee/ v12y1988i2-3 p231-254.html/09.05.2014

Johansen, S. ve Juselious, K., (1990), "Maximum Likelihood Estimation and Inference on Cointegration-with Applications to the Demand for Money", Oxford Bulletin of Economics and Statistics, 52, ss.169-210.

Karagöl, E; Erbaykal, E. ve Ertuğrul H.M., (2007), "Türkiye'de Ekonomik Büyüme İle Elektrik Tüketimi İlişkisi: Sınır Testi Yaklaşımı”, Doğuş Üniversitesi Dregisi, 8 (1), ss.72-80.

Karamustafa, O. ve Karakaya, A., (2004), "Enflasyonun Borsa Performansı Üzerindeki Etkisi”, Kocaeli Üniversitesi Sosyal Bilimler Enstitüsü Dergisi, (7), 1, ss.23-35. 
Kasekende, L., (2008), “Developing a Sound Banking System”, Paper presented at IMF Seminar, Tunisia.

Khan, M. A.; Qayyum, A. ve Saeed, A. S., (2005), "Financial Development and Economic Growth: The Case of Pakistan”, The Pakistan Development Review ,44, 4(2), ss.819837.

Khan, M.S. ve Senhadji, A.S. (2000), "Financial Development and Economic Growth: An Overview”, IMF Working Paper, WP, 00/209, December.

Kıran, B.; Yavuz, N. C. ve Guris, B., (2009), "Financial Development and Economic Growth: A Panel Data Analysis of Emerging Countries”, International Research Journal of Finance and Economics, 30, ss.87-94

King, R. G. ve Levine, R., (1993), “Finance and Growth: Schumpeter Might Be Right”, Quarterly Journal of Economics, 108(3), ss.717-737.

King, R. G. ve Levine, R., (1993b), "Finance, Entrepreneurship, and Growth: Theory and Evidence”, Journal of Monetary Economics, 32, ss.513-542.

Leitao, N. C., (2012), “Bank Credit and Economic Growth: A Dynamic Panel Data Analysis”, The Economic Research Guarrdian, Vol. 2 (2), ss.256-267

Levine, R., (1997), "Financial Development and Economic Growth: Views and Agenda”, Journal of Economic Literature, 35, ss.688-726.

Levine, R. ve Zervos, S., (1998), “Stock Markets, Banks, and Economic Growth’, American Economic Review, 88, ss.537-558.

Levine, R., Loyaza, N. ve Beck, T., (2000), "Financial Intermediation and Growth: Causality and Causes”, Journal of Monetary Economics, 46, ss.31-77

Lucas, R. E., (1988), “On the Mechanics of Economic Development”, Journal of Monetary Economics, 22 (1), ss.3-42.

Luintel, K. B. ve Khan, M., (1999), “A Quantitative Reassessment of the Finance-Growth Nexus: Evidence from Multivariate VAR”, Journal of Development Economics, Vol. 60, (2), ss.381-405.

Mishkin, F. S. (2007), “The Economics of Money and Financial Markets”, Pearson/Addison Wesley.

Murty, K. S.; Sailaja, K. ve Demissie, W. M., (2012), “The Long-Run Impact of Bank Credit on Economic Growth in Ethiopia: Evidence from the Johansen's Multivariate Cointegration Approach”, European Journal of Business and Management, (4), No.14, ss.20-33

Osterwald-Lenum, M., (1992), “A Note With Quantiles of the Asymptotic Distribution of the Maximum Likeli-hood Cointegration Rank Test Statistics”, Oxford Bulletin of Economics and Statistics, 54, 461-472, Retrieved from http://ideas.repec.org/a/bla/obuest/54y1992i3p461-72.html. 08.05.2014 
Öztürkler, H. ve Çermikli, A. H., (2007), "Türkiye'de Bir Parasal Aktarım Kanalı Olarak Banka Kredileri”, Finans Politik ve Ekonomik Yorumlar, 44(514), ss.57-68.

Rajan, R. G. ve Zingales, L., (1998), "Financial Dependence and Growth”, The American Economic Review, 88(3), ss.559-586.

Rioja, F. ve Valev, N., (2003), "Does One Size Fit All?: A Re-examination of the Finance and Growth Relationship", Social Science Research Network.

Rousseau, P.L. ve Wachtel, P., (2002), "Inflation Thresholds and The Finance-Growth Nexus”, Journal of International Money and Finance, 21, ss.777-793.

Rousseau, P.L. ve Wachtel, P., (2011), "What is Happening to The impact of Financial Deepening on Economic Growth?," Economic Inquiry, 49(1), ss.276-288.

Phillips, P.C.B., ve Perron, P., (1988), "Testing for a Unit Root in Time Series Regression”, Biometrica ,75, ss.335-46.

Saarenheimo, T., (1995), "Credit Crunch Caused Investment Slump? An Empirical Analysis Using Finnish Data”, Bank of Finland, Discussion Papers No 6/95.

Sanusi, N. A. ve Sallah, N. H. M., (2007), "Financial Development and Economic Growth in Malaysia: An Application of ARDL approach”, [Online], available: http://www. ibacnet.org/bai2007/proceedings/Papers/2007bai7443.doc. 05.03.2014

Shaw, ES., (1973), “Financial Deepening in Economic Development”, New York: Oxford University Press.

Vazakidis, A.ve Adamopoulos, A., (2011), "Credit Market Development and Economic Growth an Empirical Analysis for United Kingdom”, American Journal of Economics and Business Administration, 3 (3), ss.576-585. 